https://doi.org/10.52449/1857-4114.2020.36-2.07

CZU: 373.047:796.2

\title{
UNPROFESSIONAL PHYSICAL EDUCATION OF PRIMARY SCHOOL TEACHERS AS PART OF THE COURSE "MOLDOVAN NATIONAL DYNAMIC GAMES"
}

\author{
Samoliuc Olga ${ }^{1}$ \\ ${ }^{1}$ State University T.G. Shevchenko, Tiraspol
}

\begin{abstract}
The article presents the results of the introduction into the process of unprofessional physical education of students, the profile "Primary education" of the "Moldavan national dynamic games" course. The program of the course included in addition to traditional practical classes also methodological, lecture, laboratory, seminary and independent classes. Methodist and practical classes were devoted to studying the method of holding Moldovan national dynamic games with children. The results of the experiment demonstrate the effectiveness of the program of the course and the method of applying Moldovan folk mobile games to form the following professional-applied competencies: knowledge of the theoretic and methodical bases on native dynamic games, the ability to organize and conduct game sessions at the proper level, the formation of a number of personal qualities necessary for the implementation of pedagogical support of the game process.
\end{abstract}

Keywords: competence, primary education, unprofessional physical education, primary school teacher, national dynamic games.

Introduction. According to modern standards of education, pupils of the "Primary Education" profile as a result of mastery of the elective course on physical culture form one, but rather broad cultural competence, sounding like "training to maintain a level of physical fitness, ensuring full activity". The formulation of competence involves the task of professional and applied physical training, which in practice is extremely rare. Thus, the physical education of future primary school teachers is limited to the use of general physical fitness and is implemented in the sections "Athletics" and "Sports Games" programs on physical culture. However, considering the professional activities of these teachers, it is necessary to note the fact that graduates should become not only carriers of physical culture values, but also their translators. Among the professional duties of primary teachers include the ability at the proper level to organize physical education classes, conduct mobile games, hygienic gymnastics for children in training sessions, at recess, in extended day groups, in extracurricular work, in summer health camps [6].

In modern scientific literature, the competent approach to the training of primary school teachers is widely covered $[1,3]$. The problem of increasing the teacher's skill in these studies occupies one of the leading places, as the fading of the game subculture of childhood, the decline in the quality of children's play in the form of reluctance and inability of modern children to play joint games, neglect of the game (especially mobile) in educational institutions of different levels are markers of modern society [4]. The search for an adequate solution to the problems point to the need to introduce special courses aimed at forming professional and applied competencies for teachers, including primary schools, in the field of mobile games [10]. People's mobile games have a high pedagogical potential, which have proven their effectiveness in education, development, education of the younger generation in 
harmony with the climatic conditions of living, traditions in the upbringing of children, leisure activities, physical education $[2,5]$. In this regard, it is justified to attempt to introduce Moldovan folk mobile games into the process of non-professional physical education of pupils of the "Primary Education" profile at State University T.G. Shevchenko (Tiraspol) within the framework of an elective course and to put forward a hypothesis about its effectiveness in the formation of professional-applied competencies.

Methodology and research organization. The aim of the study is to find the best conditions for the formation of professional competences for future primary school teachers within the framework of an elective physical culture course at the university.

\section{Research objectives:}

1. To analyze literary sources on the problem of research.

2. Identify possible ways to improve the level of specialization for students in the Primary Education profile.

3. Introduce an experimental methodology and an elective course program "Mold's national dynamic games" and determine their effectiveness for the formation of professional and applied competencies.

Methods and organization of research: theoretical analysis and generalization of data of literary sources, archival method, classification, abstraction, comparison, induction, deduction, observation, socioeducational survey; assessment of the state of processes of cognitive, motivational, regulatory and volitional sphere and level of results of educational and cognitive activities; pedagogical experiment, mathematical methods of processing statistical data. The study was conducted with the participation of first-year students of the "Elementary Education" profile at Tiraspol State
University T.G. Shevchenko, who formed an experimental and control group.

The results of the study and their discussion. In the first phase of the study, an in-depth theoretical analysis of literary sources on the problem of the study was carried out. In the second stage, the quality of vocational and applied physical training of female students of the "Primary Education" specialization was studied (a survey of graduates was used, showing the low level of professional competences, formed in physical education classes at the university, monitored the process of physical education of primary school teachers at breaks, showed the fact of not doing this work), developed a professionalogram of primary school teachers (psychomotor aspect), compiled a classification of Moldovan national dynamic games, which have become a means of physical and methodical training of students.

The formative experiment was organized in natural conditions and lasted for one school year. The students of the control group were engaged in the traditional program of elective course on physical culture with the study of sports games and athletics. The programs of both groups were identical in the number of academic hours. Based on the provisions of the active and systemic approaches, an attempt was made to gradually form the pedagogical competences of the students of the "Primary Education" specialization engaged in the pilot program, with the subsequent change in both the form of physical education and their content $[7,8,9]$. As a result of these transformations, it was intended to improve the indicators of theoretical and methodical literacy in the field of physical education (cognitive competence), to develop skills at the proper professional level to conduct physical training (professional-applied competencies), to cultivate important professional qualities (pedagogical competences).

The formation of cognitive competencies was carried out in lecture and independent 
classes and included the study of the theory and methodology of physical culture on the basis of existing and supplemented during the course of knowledge from the field of physiology, hygiene and valeology. The transfer of information from teacher to pupils was conducted through communication using known methods, such as description, passage, explanation, characteristic.

Based on the results of theoretical and methodical training, in the second stage the pupils were included in practical activities, which are educational and methodical lessons. During these lessons, the participants of the experimental group had the opportunity to familiarize themselves with the structure and contents of the hygienic gymnastics' complexes, playing classes, as well as means of assessing the physical condition of the participants. During the first semester, method and practical classes were used, in which pupils took part in Moldovan national dynamic games organized by a physical education teacher. Also, with the experimental group were held complexes of hygienic gymnastics.

During the third stage, the task of practical classes planned for the second semester of the school year was the independent conduct of students of the experimental group of complexes of hygienic gymnastics and Moldovan national dynamic games, as a result of which it was necessary to acquire the pedagogical experience necessary for future specialists. The performance of female pupils in physical education classes as a teacher allowed to identify the existing knowledge, demonstrate personal qualities, apply their own skills in practice, feel like a leader, get the opportunity to observe comrades, evaluate themselves and others. The pupils were required to plan, organize and conduct physical training in the form of hygienic gymnastics and The Moldovan national dynamic game.

The organization of practical training was subordinated to the method of application of Moldovan national dynamic games, designed specifically for the implementation of the experimental program of elective course at physical culture. The games included in the technique were aimed at developing the main motor abilities of the engaged, including professionally important psychophysical qualities: speed of reaction and movement, agility, relative strength, flexibility, overall endurance and performance. The topic and rules of the games were to contribute to the manifestation of the necessary personal qualities of the teacher: attentiveness, accuracy, patience, honesty, responsibility, purposefulness, sensitivity, tactfulness, perseverance, sociability, self-control, creativity, organizational abilities, artistry. The selection of games, the dosage of playing classes were carried out in accordance with general educational principles and principles of physical education, taking into account the change in the level of performance during the school day and the working week. During the school year, the pupils took part in 36 game lessons (Table 1).

Table 1. Selection of Moldovan national dynamic games in accordance with the professionally important personal qualities of primary school teachers

\begin{tabular}{|c|c|c|}
\hline $\begin{array}{c}\text { Professional-important } \\
\text { qualities }\end{array}$ & $\begin{array}{c}\text { Moldovan national dynamic games } \\
\text { aimed at forming professional- } \\
\text { important qualities }\end{array}$ & Notes \\
\hline \multirow{3}{*}{ Observation, attention } & $\begin{array}{c}\text { «Steagul», «Ciocănitoarea», «Crabii și } \\
\text { crevețele», «Ultima pereche fouge», } \\
\text { «Atinge mingea!», «Lupii, oile și } \\
\text { păstor», «Intre două fokuri», } \\
\text { «Vînătorul, vrabia și albina», «De-a } \\
\text { trupe», «Liapșa», «Dracul șchiop», }\end{array}$ & $\begin{array}{c}\text { Games that require a quick } \\
\text { response to changing } \\
\text { conditions, the ability to } \\
\text { build tactics of their actions }\end{array}$ \\
\hline
\end{tabular}




\begin{tabular}{|c|c|c|}
\hline & $\begin{array}{c}\text { «Dansul indian», «Mingea } \\
\text { rostogolite», «Oina un cerc», «Patru } \\
\text { porți», «Băț», «Prinde bastonul!!», } \\
\text { «Inchet, Închet - departe ajunji!». }\end{array}$ & \\
\hline Accuracy & $\begin{array}{c}\text { «Atinge mingea!», «Lupii, oile și } \\
\text { păstor», «Între două fokuri», «Dansul } \\
\text { indian», «Mingea rostogolite», «Oina } \\
\text { un cerc», «Patru porți», «Bățt», «Prinde } \\
\text { bastonul!», «Închet, Închet - departe } \\
\text { ajunji!». }\end{array}$ & $\begin{array}{l}\text { Games with objects (ball, } \\
\text { stick), where the accuracy of } \\
\text { the game's actions is } \\
\text { required, as well as caution }\end{array}$ \\
\hline $\begin{array}{l}\text { Patience, ability to } \\
\text { quickly restore } \\
\text { performance } \\
\end{array}$ & $\begin{array}{c}\text { «Vînătorul, vrabia și albina», «De-a } \\
\text { trupe», «Liapşa»», «Dracul șchiop», } \\
\text { «Patru porți». }\end{array}$ & $\begin{array}{c}\text { Games in which you have to } \\
\text { fight fatigue }\end{array}$ \\
\hline $\begin{array}{l}\text { Honesty, decency, } \\
\text { integrity }\end{array}$ & \multirow{7}{*}{$\begin{array}{l}\text { «Steagul», «Ciocănitoarea», «Crabii și } \\
\text { crevețele», «Ultima pereche fouge»», } \\
\text { «Atinge mingea!», «Lupii, oile și } \\
\text { păstor», «Între două fokuri», } \\
\text { «Vînătorul, vrabia și albina», «De-a } \\
\text { trupe», «Liapșa»», «Dracul șchiop», } \\
\text { «Dansul indian», «Mingea } \\
\text { rostogolite», «Oina un cerc», «Patru } \\
\text { porți», «Băț», «Prinde bastonul!», } \\
\text { «Inchet, Închet - departe ajunji!». }\end{array}$} & \multirow{7}{*}{$\begin{array}{l}\text { Games in which you need to } \\
\text { interact with each other, } \\
\text { cooperate and compete } \\
\text { within the rules. }\end{array}$} \\
\hline $\begin{array}{l}\text { Organization, } \\
\text { Responsibility }\end{array}$ & & \\
\hline Commitment & & \\
\hline $\begin{array}{c}\text { Sensitivity, attentiveness } \\
\text { to people }\end{array}$ & & \\
\hline Tact & & \\
\hline Persistence & & \\
\hline Self-control & & \\
\hline$\frac{\text { Communication }}{\text { Creativity }}$ & \multirow[b]{2}{*}{$\begin{array}{c}\text { «Atinge mingea!», «Lupii, oile și } \\
\text { păstor», «Între două fokuri», } \\
\text { «Vînătorul, vrabia și albina», «De-a } \\
\text { trupe», «Liapșa», «Dracul șchiop», } \\
\text { «Dansul indian», «Mingea } \\
\text { rostogolite», «Oina un cerc», «Patru } \\
\text { porți»».. }\end{array}$} & \multirow[b]{2}{*}{$\begin{array}{c}\text { Games in which you need to } \\
\text { find a new solution many } \\
\text { times in the current game } \\
\text { situation. }\end{array}$} \\
\hline Flexibility of thinking & & \\
\hline $\begin{array}{l}\text { The ability to interest } \\
\text { your plan, to lead }\end{array}$ & $\begin{array}{l}\text { «Lupii, oile și păstor», «De-a trupe», } \\
\text { «Mingea rostogolite», «Patru porți». }\end{array}$ & $\begin{array}{l}\text { Team games, in which it is } \\
\text { necessary to lead the team, } \\
\text { acting as a captain, to insist } \\
\text { on the tactics of the game }\end{array}$ \\
\hline $\begin{array}{l}\text { High degree of personal } \\
\text { responsibility }\end{array}$ & $\begin{array}{l}\text { «Steagul», «Ciocănitoarea», «Crabii și } \\
\text { crevețele», «Ultima pereche fouge»», } \\
\text { «Lupii, oile și păstor», «Între două } \\
\text { fokuri», «Vînătorul, vrabia și albina», } \\
\text { «De-a trupe», «Mingea rostogolite», } \\
\text { «Oina un cerc», «Patru porți», «Băț». }\end{array}$ & $\begin{array}{l}\text { Team games in which you } \\
\text { need to make a decision for } \\
\text { other players based on their } \\
\text { interests. }\end{array}$ \\
\hline Artistry & «Dracul șchiop». & Games. \\
\hline
\end{tabular}

In the first semester, the experimental group conducted laboratory sessions that were allocated to familiarize themselves with the rules governing the physical activity of pupils and including methods for measuring heart rate, motor density of exercise and pulse curve of the lesson, diagnosis and correction of abnormalities in the health of those involved. Another topic raised in laboratory classes is the rule of first aid. In the second semester, the pupils were given the opportunity to independently measure their heart rate, conduct timekeeping of their comrades' classes, make a pulse curve of 
lessons, practically try the imposition of various bandages and other methods of premedical care for victims in the classroom.

At the beginning and end of the school year, seminars were held, during the course of which the initial and final level of the formation of professional and applied competencies for students of the "Primary Education" profile was determined in the form of knowledge of the theory and methodology of Moldovan folk mobile games, the ability to conduct a mobile game, the optimal indicators of attention distribution when working with a group, situational anxiety, motivation to exercise, personal qualities, helping to carry out high-level educational activities (Table 2).

Table 2. The intensity of the elective course physical culture

\begin{tabular}{|c|c|c|c|c|c|c|c|c|}
\hline \multirow[b]{2}{*}{ 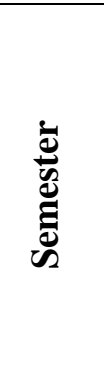 } & \multicolumn{6}{|c|}{ Classroom work (hour) } & \multirow[b]{2}{*}{ 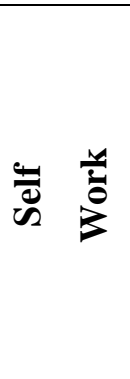 } & \multirow[b]{2}{*}{$\begin{array}{c}\text { Final } \\
\text { control form }\end{array}$} \\
\hline & 䓪 & 葛 & 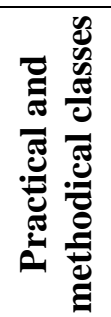 & 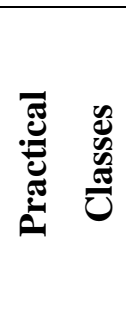 & $\frac{\mathscr{n}}{\stackrel{\mathscr{a}}{a}}$ & 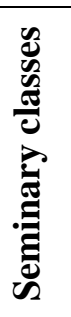 & & \\
\hline I & 68 & 10 & 36 & & 14 & 8 & 4 & $\begin{array}{l}\text { Technical } \\
\text { credit }\end{array}$ \\
\hline II & 66 & 8 & & 36 & 14 & 8 & 6 & Credit \\
\hline Total & 134 & 18 & 36 & 36 & 28 & 16 & 10 & \\
\hline
\end{tabular}

Personal participation in playing during classes, the conduct of complexes of hygienic gymnastics and dynamic games as a leader has become an effective means for the implementation of a competent approach in the unprofessional physical education of pupils profile "Primary education", which was demonstrated in the surveys and tests offered to the subjects. To assess the quality of the Moldovan national dynamic game, a special form was developed, including characteristics such as "explanation of the rules of the game," "team division, choice of leading role," "game management," "summing up the game" (Table 3).

Table 3. The form of evaluation of the Moldovan national dynamic game

\begin{tabular}{|c|c|c|}
\hline Evaluation criteria & Yes & No \\
\hline Clarity & 1 & 0 \\
\hline Availability & 1 & 0 \\
\hline Showing what you need to do & 1 & 0 \\
\hline Emotion & 1 & 0 \\
\hline The ability to captivate attention & 1 & 0 \\
\hline \multicolumn{2}{|c|}{ Points: } \\
\hline Division into teams, choice of leading role \\
\hline Impartiality & 1 & 0 \\
\hline
\end{tabular}




\begin{tabular}{|c|c|c|}
\hline $\begin{array}{c}\text { Taking into account the individual } \\
\text { characteristics of those involved }\end{array}$ & 1 & 0 \\
\hline $\begin{array}{c}\text { The ability to anticipate the outcome of } \\
\text { the game }\end{array}$ & 1 & 0 \\
\hline \begin{tabular}{c} 
Points: \\
\hline Ghe ability to insist on one's own
\end{tabular} & 1 & 0 \\
\hline \multicolumn{3}{|c|}{ Game guide } \\
\hline Timely adjustments & 1 & 0 \\
\hline $\begin{array}{c}\text { Organizational and methodical } \\
\text { instructions }\end{array}$ & 1 & 0 \\
\hline Timely points & 1 & 0 \\
\hline Injury prevention & 1 & 0 \\
\hline Emotional support & 1 & 0 \\
\hline \multicolumn{2}{|c|}{ Points: } \\
\hline Summing up the game \\
\hline
\end{tabular}

In the experimental group, the results of the experiment significantly improved the quality of dynamic game, improved the level of knowledge in the field of physical education of junior schoolchildren. By the end of the school year, the rate of situational anxiety among female pupils in the performance of the functions of the head of physical education has decreased. The results of the survey "Educational Situations" demonstrate the acquisition of valuable pedagogical experience, expressed in the manifestation of such qualities as sensitivity, self-control, tactfulness, perseverance, patience, creativity of thinking, etc. Positive, however, unreliable changes are found in the assessment of the ability to distribute attention when working with the group (Table 4).

Table 4. Student survey and testing results after the end of experiment

\begin{tabular}{|c|c|c|c|c|c|c|}
\hline \multirow{2}{*}{ Indicators } & \multicolumn{2}{|c|}{$\begin{array}{c}\text { Experimental } \\
\text { group } \\
(\mathbf{n = 2 4 )}\end{array}$} & \multicolumn{2}{c|}{$\begin{array}{c}\text { Control group } \\
\text { (n=22) }\end{array}$} & \multirow{2}{*}{$\begin{array}{c}\text { U- } \\
\text { Criteria }\end{array}$} & P \\
\cline { 2 - 6 } & $\begin{array}{c}\text { Averag } \\
\text { e }\end{array}$ & $\begin{array}{c}\text { Amount } \\
\text { of rank }\end{array}$ & Average & $\begin{array}{c}\text { Amount } \\
\text { of rank }\end{array}$ & \\
\hline The quality of the game & 4,79 & 825,5 & 2,86 & 255,5 & 2,5 & $<0,01$ \\
\hline $\begin{array}{c}\text { The level of theoretical } \\
\text { and methodical training }\end{array}$ & 4,83 & 807 & 3,6 & 274 & 21 & $<0,01$ \\
\hline $\begin{array}{c}\text { Level of situational } \\
\text { anxiety }\end{array}$ & 2,26 & 334,5 & 2,9 & 746,5 & 34,5 & $<0,01$ \\
\hline Attention-sharing level & 48,5 & 490,5 & 49,9 & 590,5 & 190,5 & $>0,05$ \\
\hline "Educational situations" & 4,7 & 797,5 & 4,0 & 283,5 & 30,5 & $<0,01$ \\
\hline
\end{tabular}

*Differences are true $U \leq 188(0,05), 158(0,01)$

During the experiment, the emotional sphere of the pupils personality improved. The survey on the method of SAM (self- feeling, activity, mood) showed a positive attitude of pupils to classes in the form of high indicators of activity and mood 
compared to the control group. Positive emotions experienced from the process of game can be the basis for the desire to play dynamic games with children in the framework of professional activities (Figure $1)$.

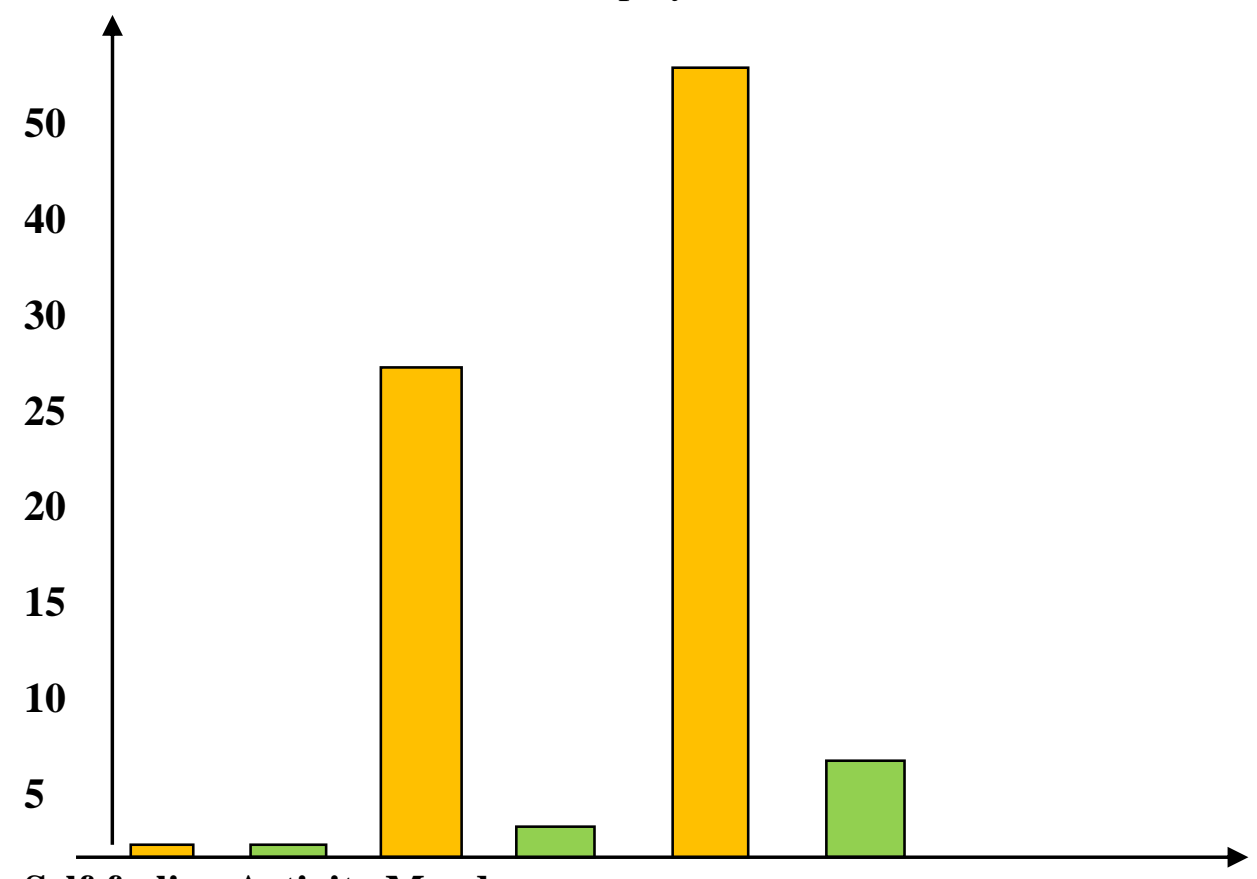

Self-feeling Activity Mood

Fig. 1. Change in well-being indicators (\%), activity, mood of female pupils during the pedagogical experiment

$\square$ - experimental group $\quad \square$-control group

The experimental group also showed better results when assessing motivation for physical activity. The inner motivation for physical education indicates that there are true reasons for pupils to take part in a course, they don't learn for marks, but for achieving the knowledge at the creative level (Figure 2).

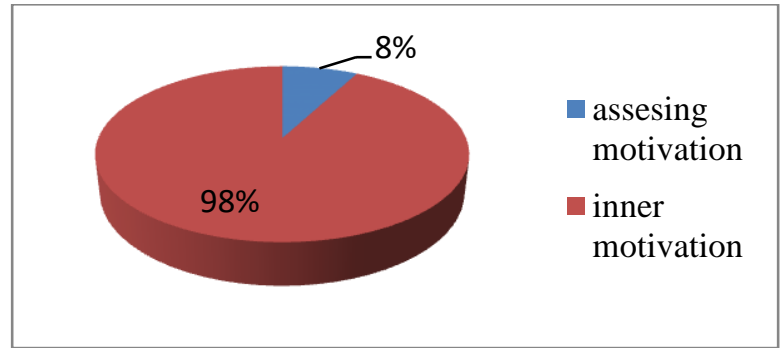

A

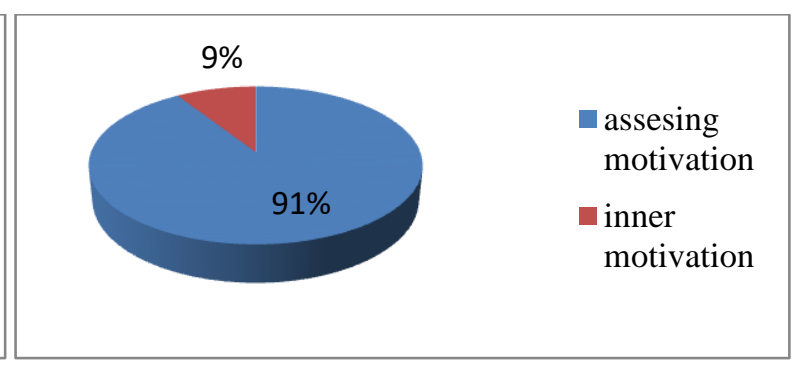

B

Fig. 2. Indicators of the activity of the student's educational motivation after the experiment: $A$ indicators of the experimental group; $B$ - indicators of the control group 
According to the pupils survey, the quality of professional-applied training in the framework of the "Moldovan national dynamic games" course has significantly improved during the experiment. Most pupils in the experimental group appreciate the knowledge and skills they gain during their classes and find them highly potential to improve their professional level of training (Figure 3).

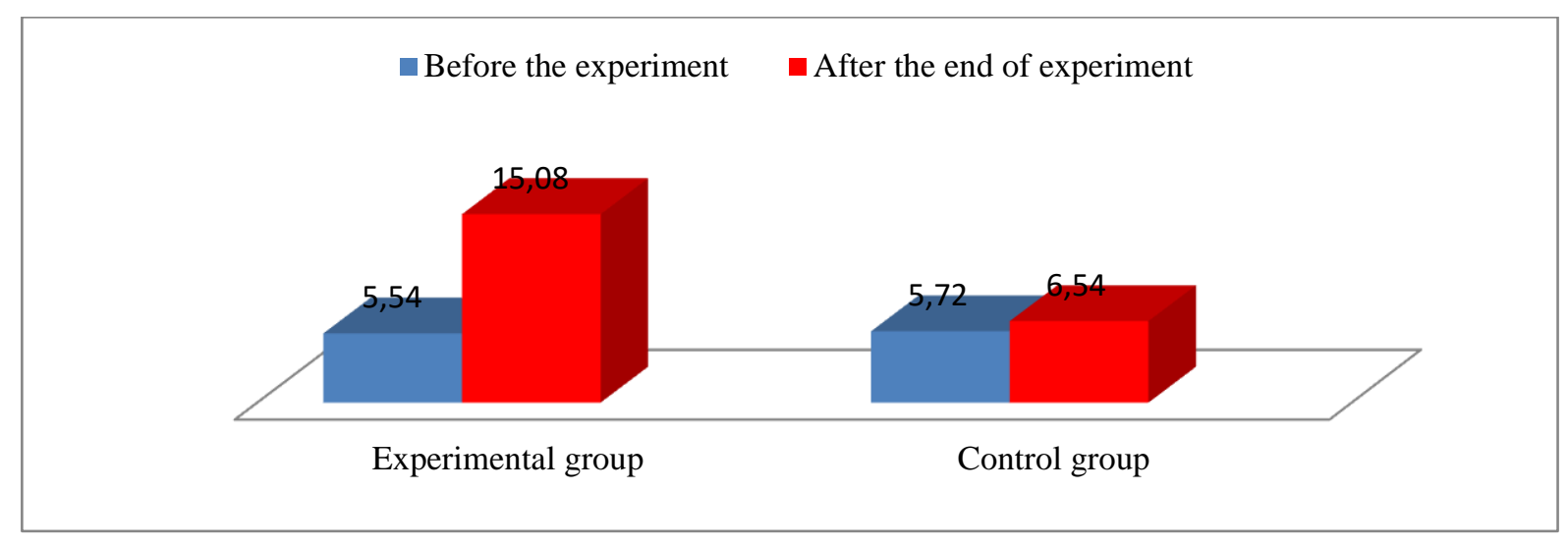

Fig. 3. Change in the performance (score) of the importance of the elective course for the training of female pupils during the period of the pedagogical experiment

Conclusions. 1. The results of the pedagogical experiment confirmed the effectiveness of the introduction of the "Moldovan national dynamic games" elective course to form professional-applied competencies among students of the Primary Education. 2. Following the provisions of active and systemic approaches has allowed to improve the following indicators: knowledge of the theoretic and methodical basis of national dynamic games, the ability to organize and conduct game classes at the proper level, the possession of a set of personal qualities necessary for the implementation of pedagogical support during the game. 3 . The results of the survey of the participants of the experiment demonstrated a high motivation for the elective course program, as well as the importance of changes in the learning process for the training of future primary school teachers.

\section{References:}

1. Алексашина А., Умерова Л.Р. (2018). Особенности профессиональной компетентности учителя начальных классов. В: Традиции и инновации в педагогике начальной школы: сборник научных трудов, посвященных 25-летию ГБОУВО КИПУ, с. 1921.

2. Алтунина О.Е., Кириллина Н.И. (2017). Применение русской лапты на уроках физической культуры в МОУ СОШ № 45 г. Орла. В: Наука-2020, № 3, с. 116-120.

3. Белова А.А., Федоренко Т.Г. (2019). Управление проиессом становления профессиональной компетентности будущих учителей начальных классов. В: Современные векторы развития образования: актуальные проблемы и перспективные решения: сборник научных трудов научно-практической конференции. В 2-х частях. Москва, 25 января 2019 г. М.: МПГУ, с. 585-588. 
4. Борисова В.Н., Максимова Л.И. (2016). Современная игровая деятельность детей как компонент детской субкультуры. В: Качество дошкольного образования: формирование социально-коммуникативной компетентности дошкольников: сборник научных трудов II-ой всероссийской научно-практической конференции, Чебоксары, 14 апреля 2016 г. Чебоксары: ЦНС «Интерактив плюс», с. 236-240.

5. Васильев Ю.А. (2016). Роль национальной игры в сочиализации дошкольников в условиях сельской ДОО. В: Качество дошкольного образования: формирование социальнокоммуникативной компетентности дошкольника: сборник научных трудов II-ой всероссийской научно-практической конференции, Чебоксары, 14 апреля 2016 г. Чебоксары: ЦНС «Интерактив плюс», с. 240-244.

6. Горохова Ю.В. (2015). Роль учителя в современной школе. В: Педагогическое мастерство: материалы VII Междунар. научно-практич. Конференции. Москва: Буки-Веди, с. 8-10. Режим доступа: https://moluch.ru/conf/ped/archive/184/9055/ (дата обращения: 14.09.2020)

7. Данаил С.Н., Тимуш М. Данаил С.С. (2015). Особенности построения программы поэтапного формирования дидактических компетенций будущих учителей физической культуры. В: Университетский спорт в современном образовательном социуме: Материалы междунар. науч. - практ. конф. , 23-24 апреля 2015 г, ч.1. Минск: БГУФК, с. 90-93.

8. Зимняя И.А. (2009). Ключевые компетенции - новая парадигма результата образования. В: Эксперимент и инновации в школе, №2, с. 7-14.

9. Исследования гуманитарных систем, вып. 1. (2013). Теория педагогической системы Н.В. Кузьминой: генезис и следствия. Краснодар: Парабеллум. 90 с.

10. Смирнова Е.О., Соколова М.В., Котляр И.А. (2014). Отчет о ХІХ всемирной конференции Международной ассоциации игры (International Play Association (IPA). B: Культурно-историческая психология, Т. 10, № 2, с. 105-109. 